\title{
UBI JALAR SEBAGAI SALAH SATU ALTERNATIF PENGEMBANGAN PRODUK SNACK
}

\author{
Ani Nuraeni ${ }^{1)}$ Thalita Fauziah ${ }^{2)}$ \\ Dosen Tetap Program Keahlian Manajemen Industri Jasa Makanan dan Gizi, \\ Program Diploma-Institut Pertanian Bogor; ${ }^{2}$ Mahasiswa Program Keahlian \\ Manajemen Industri Jasa Makanan dan Gizi, Program Diploma-Institut Pertanian \\ Bogor \\ email: ani.hanhan@gmail.com
}

\begin{abstract}
The general purpose of product development of snack made from sweet potato. Product development is very important thing to do to make consumers do not feel bored with product that already on the market and make a product with better quality and benefits. Product development has a purpose to improve and complete the product that already exist. The product that will be developed is a snack from sweet potato. Snack from sweet potato has not been a common in the market. This product development has been done to inform the society that the food from sweet potato can be a very delicious and nutritious snack. Sweet potato was chosen because it is easy to find with inexpensive price, easy to process, have good nutrition for body, and have a longer shelf life.
\end{abstract}

Keywords : Development of products, snack, sweet potato

\begin{abstract}
ABSTRAK
Tujuan umum dari penelitian ini adalah melakukan pengembangan produk snack berbahan dasar ubi jalar. Pengembangan produk sangat penting dilakukan agar konsumen tidak merasa bosan dengan produk yang ada dipasaran dan terciptanya produk dengan kualitas dan manfaat yang lebih baik. Pengembangan produk memiliki tujuan untuk perbaikan produk atau menyempurnakan produk yang sudah ada sebelumnya. Produk yang akan dikembangkan berupa snack berbahan dasar ubi jalar. Pengembangan produk dilakukan karena ingin memberitahukan kepada masyarakat bahwa hidangan yang diolah dari bahan ubi jalar tersebut dapat dijadikan snack yang tak kalah lezat dan bergizi. Ubi jalar dipilih karena mudah didapat dengan harga yang terjangkau, mudah dalam pengolahan, memiliki nutrisi yang baik bagi tubuh, dan mempunyai daya simpan yang lebih lama. Pengembangan snack yang dilakukan adalah membuat pie, bolu kukus dan panada berbahan ubi jalar, ketiga hidangan yang dikembangkan merupakan pengembangan dari snack manis dan snack asin, dimana pie dan bolu kukus merupakan pengembangan produk snack manis sedangkan panada merupakan pengembangan produk dari snack asin. Pie biasanya diisi dengan menggunakan susu yang dibuat vla ditambahkan dengan berbagai macam buah-buahan, selain itu juga bisa di tambahkan daging dan keju, sedangkan bolu kukus dikembangkan dengan memberikan campuran ubi jalar pada bolu kukus serta menambahkan pure ubi pada lapisan bolu kukus tersebut, sedangkan panada merupakan snack asin yang termasuk ke dalam kelompok roti goreng yang biasa diisi dengan ikan tongkol. Penggunaan bahan ubi jalar dalam pengembangan produk karena mudah di dapat di pasaran, harga terjangkau, memiliki daya simpan yang lama tetapi memiliki nutrisi yang baik bagi tubuh. Penelitian mengenai pengembangan produk snack berbahan dasar ubi jalar dimulai dari pengadaan bahan, produksi, serta mengetahui tingkat kesukaan konsumen terhadap produk yang telah dikembangkan, juga tidak lupa menghitung kandungan gizi yang terdapat dalam ketiga produk snack tersebut.
\end{abstract}

Kata Kunci : Pengembangan produk, snack, ubi jalar 


\section{PENDAHULUAN}

Produk adalah setiap tawaran yang dapat memuaskan kebutuhan pasar, memuaskan kebutuhan dan keinginan konsumen. Produk dapat berupa barang, jasa, pengalaman, peristiwa, orang, tempat, kepemilikan, organisasi, informasi, dan ide. Produk juga dapat dikatakan seperangkat atribut baik berwujud maupun tidak berwujud, termasuk di dalamnya masalah warna, harga, nama baik pabrik, nama baik toko yang menjual, dan pelayanan pabrik serta pelayanan penjual, yang diterima oleh pembeli guna memuaskan keinginannya (Muhardi 2007).

Pengembangan produk merupakan suatu kegiatan memodifikasi resep hidangan yang bertujuan untuk memperbaiki produk yang sudah ada sehingga menjadi lebih baik dan lebih bermanfaat dari produk sebelumnya. Pengembangan produk dapat dilakukan dengan cara memodifikasi bahan baku, teknik pengolahan, bentuk hidangan, warna serta rasa dari hidangan yang bertujuan untuk meningkatkan kepuasan konsumen atau pelanggan. Pengembangan produk dapat dilakukan pada berdasarkan kerangka menu seperti makanan pokok, lauk hewani, lauk nabati, maupun snack. Pengembangan produk yang dilakukan pada penelitian ini adalah pengembangan produk hidangan snack.

Snack merupakan istilah bagi makanan yang bukan merupakan menu utama (makan pagi, makan siang atau makan malam). Snack biasanya dikonsumsi diantara waktu makan utama. Makanan yang dimaksud adalah makanan untuk menghilangkan rasa lapar seseorang sementara waktu, memberi sedikit pasokan energi dan zat gizi ke tubuh, atau sesuatu yang dimakan untuk dinikmati rasanya. Produk yang akan dikembangkan berupa hidangan snack. Bahan dasar yang digunakan pada pengembangan produk snack ini adalah ubi jalar, ubi jalar yang digunakan adalah ubi jalar merah dan tepung ubi jalar putih. Snack yang dikembangkan merupakan produk yang di modifikasi dari segi bahan, bentuk, dan warna.

Pada pengembangan produk dipilih ubi jalar merah dengan pertimbangan mudah didapat, dengan harga yang terjangkau, serta mudah dalam pengolahan dan memiliki nutrisi yang baik tubuh. Sedangkan tepung ubi jalar putih dipilih karena tepung ini merupakan olahan dari ubi jalar yang cocok digunakan untuk mengolah berbagai macam hidangan, memiliki daya simpan lebih lama, dan belum banyak hidangan berbahan dasar tepung ubi di pasaran. Kesadaran masyarakat akan kualitas hidup dan pentingnya makanan sehat dan bergizi mendorong pengembangan produk dilakukan agar produk tetap dikenal di pasaran, konsumen tidak merasa bosan dengan produk yang ada, serta terciptanya produk dengan kualitas serta manfaat yang lebih baik.

Berdasarkan paparan di atas yang menjadi fokus masalahnya yaitu, (1) Bagaimana memproduksi snack berbahan dasar ubi jalar, (2) Sejauhmana pengadaan bahan snack berbahan dasar ubi jalar merah dan tepung ubi jalar putih beserta siklus menu (3) Seberapa besar kandungan gizi pada snack berbahan dasar ubi jalar merah dan tepung ubi jalar putih, serta (4) Bagaimana daya terima konsumen terhadap snack berbahan dasar ubi jalar merah dan tepung ubi jalar putih

Tujuan dari pengembangan hidangan snack berbahan dasar ubi jalar bertujuan untuk (1) Memproduksi produk snack manis dan asin berbahan dasar ubi jalar, yaitu dari ubi jalar merah dan tepung ubi jalar putih, (2) Mengkaji pengadaan bahan snack berbahan dasar ubi jalar merah dan tepung ubi jalar putih beserta siklus menu, (3) Menghitung kandungan gizi pada snack berbahan dasar ubi jalar merah dan tepung ubi jalar putih, serta (4) Menganalisis daya terima konsumen terhadap snack berbahan dasar ubi jalar merah dan tepung ubi jalar putih. 


\section{METODE PENELITIAN}

Penelitian dalam melakukan pengembangan snack berbahan dasar ubi jalar ini dilakukan di Laboratorium Kulinari dan Diet Gedung CA Kampus Diploma IPB Cilibende, yang berlangsung selama empat bulan. Satu hari produksi dapat menghasilkan 10 hingga 12 kemasan snack. Kegiatan produksi dilakukan mulai tanggal 17 Februari 2016 sampai tangga 16 Juni 2016, dilakukan tiga sampai empat kali dalam seminggu, mulai pukul 07.30 WIB sampai dengan pukul $15.00 \mathrm{WIB}$.

Pengambilan data dilakukan dengan cara pengamatan dan praktik secara langsung mulai dari proses perencanaan bahan sampai dengan pemasaran snack. Ada enam pengambilan data yang dilakukan berupa keadaan umum Laboratorium Kulinari dan Diet dengan melakukan pengamatan secara langsung, kemudian pengadaan dan penyimpanan bahan snack dengan cara melakukan perencanaan, pembelian, dan penyimpanan bahan makanan secara langsung.

Produksi snack dilakukan dengan tahapan proses persiapan, pengolahan, dan pemorsian serta pengemasan, setelah itu dilakukan pemasaran snack secara langsung dengan sasaran konsumen adalah mahasiswa dan civitas akademika di Program Diploma IPB, kemudian menghitung kandungan energi dan zat gizi snack berdasarkan DKBM. Analisis daya terima konsumen dengan cara memberikan uji organoleptik kepada konsumen dan melakukan analisis biaya bahan snack dengan menghitung harga bahan yang digunakan untuk hidangan yang akan diolah.

\section{HASIL DAN PEMBAHASAN}

\section{Gambaran Umum Produk}

Aspek yang perlu diperhatikan dalam pengembangan produk terdiri dari sifat produk, cara pengolahan, dan ketersediaan bahan baku. Sifat produk terbagi menjadi tiga yaitu, inovatif, modifikatif, dan imitatif. Cara pengolahan yang digunakan dalam pengembangan produk harus mudah dan sederhana, serta teknologi dan peralatan yang digunakan harus tersedia dan mudah didapat. Bahan yang digunakan untuk pengembangan produk adalah bahan yang banyak tersedia dilingkungan sekitar wilayah produksi. Ketersediaan bahan baku meliputi jumlah bahan yang tersedia, kontinyuitas pengadaan bahan, harga bahan baku, dan kemudahan untuk mendapatkan bahan.

Produk yang akan dikembangkan berupa snack berbahan dasar ubi jalar, ubi jalar yang digunakan adalah ubi jalar merah dan tepung ubi jalar putih. Selama ini kita belum banyak menjumpai hidangan snack yang menggunakan bahan ubi jalar merah dan tepung ubi jalar putih. Pengembangan produk yang dilakukan ingin mengedukasi masyarakat bahwa hidangan yang diolah dari bahan ubi jalar dapat dijadikan snack yang tak kalah lezat, sehat,bergizi, dan menarik.

Produk snack yang akan dikembangkan menjadi dua macam snack, yaitu snack asin dan snack manis. Produk snack yang dikembangkan terdiri dari tiga hidangan yaitu panada ubi, bolu kukus ubi, dan pie ubi. Dalam melakukan pengembangan produk snack asin dalam bentuk panada, peneliti mencoba untuk membuat variasi rasa yang berbeda dengan produk sebelumnya. Padana adalah salah satu jenis hidangan roti goring yang memiliki rasa asin dan pedas yang terbuat dari ikan tongkol, penulis mencoba untuk menambahkan ubi jalar dalam pembuatan roti serta membuat variasi isi yang berbeda. Ikan tongkol yang di tumis diganti dengan menggunakan ubi jalar yang dibuat pure,

Bolu kukus ubi dipilih untuk dikembangkan karena bolu kukus yang dijual di pasaran hanya terdiri dari adonan bolu saja tanpa tambahan bahan lain seperti bahan isi. Pembuatan bolu kukus dengan menambahkan ubi jalar yang telah dikukus dan dihaluskan pada adonan bolu dengan tujuan untuk memperoleh cita rasa bolu 
kukus yang berbeda dengan bolu biasanya, selain itu juga menambahkan pure ubi pada lapisan bolu kukus.

Pie ubi dipilih untuk dikembangkan karena hidangan pie umumnya selalu berisi vla susu dengan potongan buah, sehingga penulis perlu melakukan pengembangan produk pie dengan bahan isi vla dari ubi jalar dengan tujuan untuk menambah variasi rasa sehingga konsumen tidak merasa bosan dengan jenis pie yang sudah ada, selain itu juga dari segi warna pie ubi jalar lebih manarik karena adanya kombinasi antara warna kekuningan dari kulit pie dan warna orange dari vla ubi jalar yang terbuat dari jenis ubi jalar berwarna orange.

\section{Proses Produksi Hidangan Snack Berbahan Dasar Ubi}

Tahapan yang harus dilakukan sebelum kita melakukan pengolahan makanan diawali dengan tahap perencanaan, pengadaan bahan makanan (pembelian, penerimaan dan penyimpanan), dan produksi makanan (persiapan, pengolahan, penyajian atau pemorsian). Tujuan dari perencanaan bahan makanan adalah agar tersedianya taksiran macam dan jumlah bahan makanan dengan spesifikasi yang ditetapkan, dalam kurun waktu yang ditetapkan. Perencanaan bahan ini mengikuti jenis dan jumlah bahan berdasarkan resep dan jumlah porsi. Bahan kering direncanakan selama empat hari sekali, sedangkan bahan basah direncanakan setiap hari.

Pengadaan bahan makanan dilakukan untuk memenuhi kebutuhan pengolahan bahan makanan hingga makanan dapat disajikan maupun dipasarkan. Pengadaan bahan meliputi perencanaan, pembelian dan pemesanan. Pengadaan bahan makanan untuk hidangan snack berbahan dasar ubi jalar ini dilakukan satu hari sebelum hari produksi.

Proses produksi diawali oleh proses persiapan. Tujuan dari kegiatan persiapan pengolahan yaitu untuk menunjang proses suatu kegiatan agar dapat terselenggara dengan baik dan tepat waktu, serta mudah dan menyenangkan bagi juru masak maupun bagi orang yang akan menikmatinya. Ada dua persiapan yang dilakukan dalam produksi snack ubi jalar yaitu persiapan alat dan bahan.

Pada saat melakukan persiapan kegiatan yang dilakukan adalah menyiapkan bahan yang akan digunakan dengan cara mencuci, membersihkan dan memotong bahan makanan yang akan digunakan, sedangkan persiapan alat yang dibutuhkan dalam membuat semua snack yang dikembangkan adalah talenan, pisau, timbangan, gelas ukur serta blender. Alat pengolahan nya terdiri dari kompor, wajan, dandang, sutil, panic bertangkai, dan Waskom.

Persiapan alat dan bahan merupakan kegiatan yang menentukan keberhasilan dari suatu rangkaian produksi makanan, jika tahap persiapan dilakukan dengan baik dan sesuai edngan prosedur pengolahan makan akan menentukan proses selanjutnya yaitu pengolahan makanan.

\section{- Panada Ubi}

Hidangan panada dipilih untuk dikembangkan karena belum banyak dijual dipasaran. Panada yang diproduksi adalah panada ubi isi ayam dan panada ubi isi pisang. Bahan kulit panada dibuat dari tepung terigu dan tepung ubi jalar putih. Bahan isi panada asin diganti menjadi daging ayam dengan wortel dan kentang. Bahan ini dipilih dengan alasan tidak begitu banyak masyarakat yang suka mengkonsumsi hidangan ikan cakalang atau tongkol dan daging ayam dipilih karena mayoritas masyarakat menyukai daging ayam.

Pengadaan bahan dan persiapannya mudah dilakukan serta nilai gizi hidangan bertambah karena adanya tambahan sayuran. Bahan isi panada manis dibuat dari pisang nangka, alasan pisang dipilih karena pisang mudah didapat, harga terjangkau, dan rasanya cocok untuk bahan isi. Pisang nangka dipilih karena pisang 
nangka memiliki tekstur yang agak keras cenderung tidak mudah lembek dan memiliki rasa manis sedikit asam.

Pengolahan panada ubi isi ayam dan panada ubi isi pisang sama. Pengolahan dimulai dengan membuat adonan roti untuk kulit panada dari bahan kulit yang sudah disiapkan. Fermentasi pertama dilakukan selama 15 menit, setelah itu adonan di keluarkan, ditimbang dan dibagi menjadi 20 bagian. Berat adonan perbagian adalah $26 \mathrm{~g}$. Setelah itu, adonan yang sudah dibagi dibulatkan dan difermentasi kembali di tempat yang sama selama 15 menit.

Adonan yang telah selesai difermentasi kemudian digiling menggunakan rolling pin. Adonan di letakkan di atas cetakan pastel yang sudah ditaburi tepung terigu. Adonan kulit dalam cetakan diisi dengan bahan isi ayam atau pisang dengan berat $40 \mathrm{~g}$. Setelah itu adonan dicetak dengan cara direkatkan dan diolesi air terlebih dulu, waktu yang diperlukan sebanyak 30 menit.

Panada yang sudah dicetak kemudian digoreng di dalam minyak banyak hingga terendam (deep frying). Penyelesaian dalam pengolahan panada dengan memperindah tampilan panada. Panada ubi isi ayam akan diberi tambahan saus pedas pada bagian atasnya dengan membentuk garis zigzag. Panada ubi isi pisang diberi tambahan pasta coklat dengan membentuk garis zigzag dan terakhir diberi taburan butiran permen warna-warni. Selain untuk memperindah penampilan panada, hal ini dilakukan untuk membedakan panada dengan cita rasa asin dengan manis.

\section{- Bolu Kukus Ubi}

Bolu kukus yang diproduksi adalah bolu kukus ubi lapis coklat dan bolu kukus ubi lapis tumis ayam sayuran. Pada pengembangan produk kali ini, bolu dimodifikasi berdasarkan bahan, baik bahan baku dan bahan isi, warna produk serta bentuk bolu. Bahan baku bolu kukus ubi ini sama saja seperti bahan bolu kukus pada umumnya, hanya saja adonan bolu dicampurkan dengan ubi jalar merah yang sudah dikukus dan dihaluskan sebelumnya. Ubi ini dicampurkan agar menghasilkan warna jingga alami pada bolu sehingga terlihat lebih menarik, selain itu juga ubi jalar yang digunakan dapat sekaligus sebagai pewarna alami. Dengan adanya penambahan ubi jalar yang dihaluskan juga dapat membuat tekstur menjadi lebih empuk dan lembut . Warna bolu kukus biasanya didapat dari pewarna makanan buatan seperti warna hijau, dan merah muda. Bolu kukus umumnya dibuat menggunakan cetakan bolu kukus sehingga, hasil yang didapat mengembang dan mekar. Pada pengembangan ini bolu kukus dibuat dengan menggunakan loyang, menyerupai bolu yang diolah dengan cara dipanggang tetapi bolu ini tetap mengembang namun tidak mekar. Penggunaan loyang digunakan untuk mempermudah produksi bolu dan mempercepat waktu produksi.

Pengolahan bolu kukus ubi lapis coklat dan bolu kukus ubi lapis tumis ayam sayuran sama. Pengolahan dimulai dengan mengocok telur bersama gula pasir, ovalet dengan mixer selama tujuh menit sampai adonan manjadi kaku. Kemudian ke dalam adonan dicampurkan bahan tepung yang sudah diayak, pencampuran dilakukan sedikit-sedikit sambil diaduk melipat. Hal ini dilakukan agar ada udara yang masuk ke dalam adonan sehingga bolu yang dihasilkan menggembang dan berpori. Tambahkan campuran mentega cair dan santan ke dalam adonan. Terakhir adalah pencampuran ubi jalar merah yang sudah dikukus dan dihaluskan. Pencampuran dilakukan sedikit-sedikit dan tetap diaduk melipat. Adonan yang sudah tercampur dituang ke dalam loyang dan dikukus (steaming).

Pengolahan bolu kukus ubi lapis tumis ayam sayuran dibuat menjadi tiga lapis, namun pengocokkan dan pencampuran bahan hanya dilakukan sebanyak dua kali. Pengocokkan dan pencampuran bahan tersebut dilakukan untuk lapisan pertama dan terakhir. Lapisan kedua adonan ini berisi tumis ayam sayuran tanpa dicampur dengan bahan lain. Lapisan adonan pertama dikukus selama 10 menit, 
lapisan adonan kedua dikukus selama 5 menit, dan lapisan terakhir selama 15 menit. Total waktu yang diperlukan untuk mengukus adalah 30 menit.

Penyelesaian dari pengolahan bolu kukus ubi ini, yaitu pemotongan bolu. Satu loyang bolu dipotong menjadi 12 bagian, sehingga menghasilkan 12 potong bolu kukus ubi lapis coklat dan 12 potong bolu kukus ubi lapis tumis ayam sayuran. Kendala yang ditemukan selama pengolahan bolu kukus ubi yaitu lapisan atas bolu yang tidak rata.

\section{- Pie Ubi}

Pada pembuatan kulit pie sama seperti pada pembuatan kulit pie pada umumnya, hanya terdapat tambahan tepung ubi jalar putih. Kulit pie manis dan pie asin dibedakan berdasarkan warna, pie manis kulitnya berwarna coklat tua karena diberi tambahan bubuk coklat. Bahan isi dipilih karena belum terdapat pie isi vla ubi yang dijual dipasaran. Bahan isi pie asin adalah ragout ayam dengan sayuran seperti jagung manis, wortel, dan buncis.

Pengolahan pie ubi dimulai dengan mencampurkan bahan kulit dan diaduk menggunakan garpu. Cetakan pie yang sudah disiapkan diolesi oleh margarin terlebih dahulu. Adonan kulit yang sudah tercampur rata digiling dengan menggunakan rolling pin dan dicetak ke dalam cetakan pie, dibentuk, dan dirapikan. Penggilingan dan pencetakan kulit dilakukan selama 30 menit untuk 26 buah pie. Setelah itu pie dipanggang di dalam oven bersuhu $170^{\circ} \mathrm{C}$ yang sebelumnya sudah dipanaskan terlebih dahulu. Sebelum di panggang adonan kulit ditusuk-tusuk menggunakan garpu agar adonan tidak mengembang dan retak.

Teknik pengolahan pemanggangan ini dikenal dengan nama baking. Kendala yang ditemukan selama pengolahan pie ubi yaitu kulit pie yang susah dilepaskan dari cetakan dan kulit pie asin yang kurang kering. Pemanggangan kulit pie ubi isi ragout ayam sayuran dilakukan selama 25 menit. Kulit pie yang sudah matang di keluarkan dari oven dan didinginkan. Setelah itu, setiap pie diisi dengan ragout ayam sayuran. Penyelesaian dari hidangan ini adalah menutup bagain atas pie dengan sisa adonan yang dibentuk seperti anyaman silang untuk memperindah penampilan pie. Setelah itu, diolesi dengan putih telur dan dipanggang untuk kedua kalinya. Pie ubi isi ragout ayam sayuran yang dihasilkan sebanyak 12 buah.

Pemanggangan kulit pie ubi coklat dilakukan selama 20 menit. Kulit pie yang sudah matang di keluarkan dari oven dan didinginkan. Selagi menunggu kulit pie didinginkan, vla ubi untuk isi pie dibuat. Jus ubi, maezena, agar didihkan sampai mengental. Kulit pie dikeluarkan dari cetakan secara perlahan dan disi dengan vla ubi. Penyelesaian dari hidangan ini dibagian tengah pie diberi potongan cherry merah untuk memperindah penampilan pie. Pie ubi coklat yang dihasilkan sebanyak 14 buah.

Pemorsian hidangan snack ubi jalar dilakukan setelah proses pengolahan selesai. Snack yang sudah dingin ditempatkan ke dalam plastik mika yang sebelumnya sudah diberi alas kertas cupcake. Satu plastik mika berisi dua buah snack, yaitu satu buah snack asin dan satu buah snack manis. Pemorsian dilakukan dengan menggunakan sendok dan pisau.

Standar porsi hidangan snack berbahan dasar ubi jalar ini berbeda-beda. Standar porsi ini untuk bahan makanan yang sudah diolah, kemudian ditimbang berat matangnya dan dihitung rata-ratanya. Standar porsi masing-masing hidangan dapat dilihat pada Tabel 1.

Tabel 1 Pengembangan Produk Snack Berbahan Dasar Ubi Jalar

\begin{tabular}{|c|c|c|}
\hline No & Nama Hidangan & Standar Porsi $(\mathrm{g})$ \\
\hline 1 & Panada Ubi Isi Ayam & 60 \\
\hline
\end{tabular}




\begin{tabular}{|c|l|l|}
\hline 2 & Panada Ubi Isi Pisang & 55 \\
\hline 3 & Bolu Kukus Ubi Lapis Coklat & 50 \\
\hline 4 & Bolu Kukus Ubi Lapis Tumis Ayam Sayuran & 50 \\
\hline 5 & Pie Ubi Coklat & 50 \\
\hline 6 & Pie Ubi Isi Ragout Ayam Sayuran & 50 \\
\hline
\end{tabular}

Sumber : data uji coba pengembangan produk 2016

\section{Pengemasan}

Pengemasan dapat dijadikan sebagai sarana promosi untuk menarik daya beli konsumen. Bentuk, warna, dan bahan kemasan perlu direncanakan dengan baik. Kemasan merupakan faktor penting dalam upaya untuk memastikan bahwa makanan atau minuman yang dihasilkan mudah didistribusikan dan aman. Bahan kemasan yang digunakan untuk snack ubi jalar ini terbuat dari plastik yaitu plastik mika sebagai kemasan primer dan kertas cupcake sebagai kemasan sekunder.
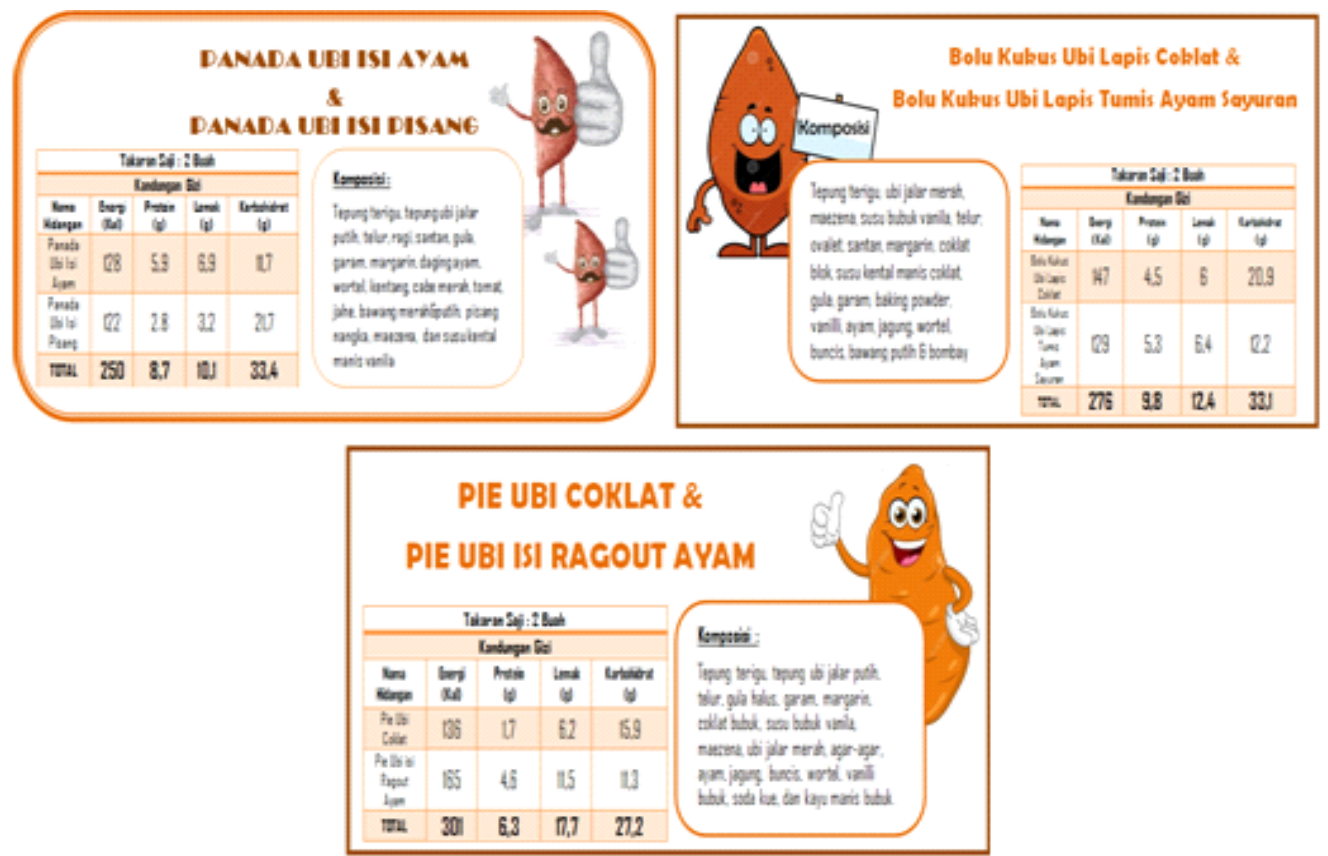

Gambar 1 Label produk olahan snack berbahan dasar ubi jalar

Pada bagian atas kemasan ditempel label produk. Labeling merupakan bagian dari proses pengemasan yang harus diperhatikan karena memiliki peran yang sangat penting. Label berfungsi memberikan informasi kepada calon konsumen mengenai produk, komposisi produk, cara penggunaan produk, cara menyimpan hingga cara memasak. Label harus dibuat semenarik mungkin agar dapat menarik minat konsumen untuk membeli produk tersebut. Desain untuk label kemasan ketiga produk snack dapat dilihat pada Gambar 1. Informasi yang terdapat pada label produk snack ubi jalar ini diantaranya nama menu, komposisi, takaran saji, dan kandungan energi serta zat gizi.

\section{Perkembangan Produk}


Produksi hidangan snack berbahan dasar ubi jalar mengalami perkembangan dari waktu ke waktu selama pengolahan. Uji resep awal dilakukan untuk menentukan resep dan produk yang sesuai. Panada ubi dan pie ubi dilakukan satu kali uji resep awal, sedangkan bolu kukus ubi dengan dua kali uji resep awal.

Perkembangan panada ubi yang terjadi yaitu pada cara mengolah hidangan panada. Pada percobaan pertama panada ubi dibuat dan dipilin manual, pada pengolahan kedua panada ubi dibuat menggunakan cetakan pastel. Pengolahan pertama panada ubi isi pisang tidak diberi garnish. Pada pengolahan pertama warna panada gelap karena garnish yang diberikan pada panada ubi isi pisang hanya pasta coklat. Pada pengolahan berikutnya panada pisang diberi butiran permen warnawarni sebanyak $6 \mathrm{~g}$ untuk 10 buah panada isi pisang. Penambahan ini dilakukan untuk memperindah penampilan panada.

Bolu kukus ubi mengalami perkembangan dan pergantian resep pada minggu kedua pengolahan. Lapisan coklat di tengah bolu kukus ubi yang dibuat pada pengolahan minggu pertama diolah berdasarkan $35 \mathrm{~g}$ lelehan coklat batang dan $37 \mathrm{~g}$ susu kental manis coklat yang diaduk rata. Lapisan coklat pada bolu menyebar kebagian samping bolu. Oleh karena itu, dilakukan perubahan resep agar lapisan coklat tidak menyebar dengan menambahkan adonan. Hidangan pie ubi juga mengalami perkembangan dan perbaikan resep. Pada pengolahan minggu pertama kulit pie ubi tidak begitu renyah setelah dipanggang. Pada pengolahan ke empat beberapa bahan diresep diganti jumlahnya dan penggunaan air untuk kulit pie dihilangkan.

\section{Kandungan Energi dan Zat Gizi}

Kandungan gizi ketiga snack ubi jalar dihitung dengan melihat jenis dan jumlah bahan yang digunakan untuk satu kali produksi. Kandungan energi dan zat gizi ini dihitung menggunakan DKBM. Kandungan gizi pada snack ubi jalar meliputi energi, protein, karbohidrat, dan lemak.

Tabel 2. Kandungan Gizi Pengembangan Produk Snack Berbahan Dasar Ubi Jalar

\begin{tabular}{|l|l|c|c|c|c|}
\hline \multirow{2}{*}{ No } & Jenis Hidangan & \multicolumn{4}{|c|}{ Kandungan Gizi } \\
\cline { 3 - 6 } & & $\begin{array}{c}\text { Energi } \\
(\mathrm{Kal})\end{array}$ & $\begin{array}{c}\text { Protein } \\
(\mathrm{g})\end{array}$ & $\begin{array}{c}\text { Lemak } \\
(\mathrm{g})\end{array}$ & $\begin{array}{c}\text { Karbohidrat } \\
(\mathrm{g})\end{array}$ \\
\hline 1. & Panada Ubi Jalar & 250 & 8,7 & 10,1 & 33,4 \\
\hline 2. & Bolu Kukus & 276 & 9,8 & 12,4 & 33,1 \\
\hline 3. & Pie Ubi & 301 & 6,3 & 17,7 & 27,2 \\
\hline
\end{tabular}

Sumber : data uji coba pengembangan produk 2016

Diantara ketiga hidangan snack yang diproduksi, pie ubi memiliki kandungan energi dan zat gizi paling tinggi. Hal ini dikarenakan penggunaan margarin yang banyak pada hidangan pie ubi. Berdasarkan syarat jumlah kalori snack yaitu 150-200 $\mathrm{Kal}$, ketiga hidangan snack ubi jalar sudah memenuhi jumlah kalori yang berkisar 250-300 Kal.

\section{Daya Terima Konsumen}

Daya terima konsumen merupakan penilaian yang dilakukan konsumen terhadap suatu hidangan sejauh mana produk yang diolah telah diterima oleh konsumen atau tidak. Untuk melihat daya terima konsumen dilakukan uji berupa uji organoleptik pada hidangan pengembangan produk snack ubi jalar. Panelis pada pengembangan produk ini yaitu mahasiswa Diploma IPB, dosen dan masyarakat sekitar kampus. Penilaian uji organoleptik meliputi rasa, tekstur, aroma, dan penampilan. Uji organoleptik dilakukan kepada 10 orang konsumen untuk setiap uji coba resep, dimana yang menjadi panelis adalah mahasiswa program diploma IPB yang membeli produk. Hasil uji organoleptik dibuatkan menjadi data berupa diagram. 
Produk pertama yang dilalukan uji organoleptik yaitu produk panada yang dibuat menjadi dua versi yaitu panada isi ayam dan panada isi pisang.

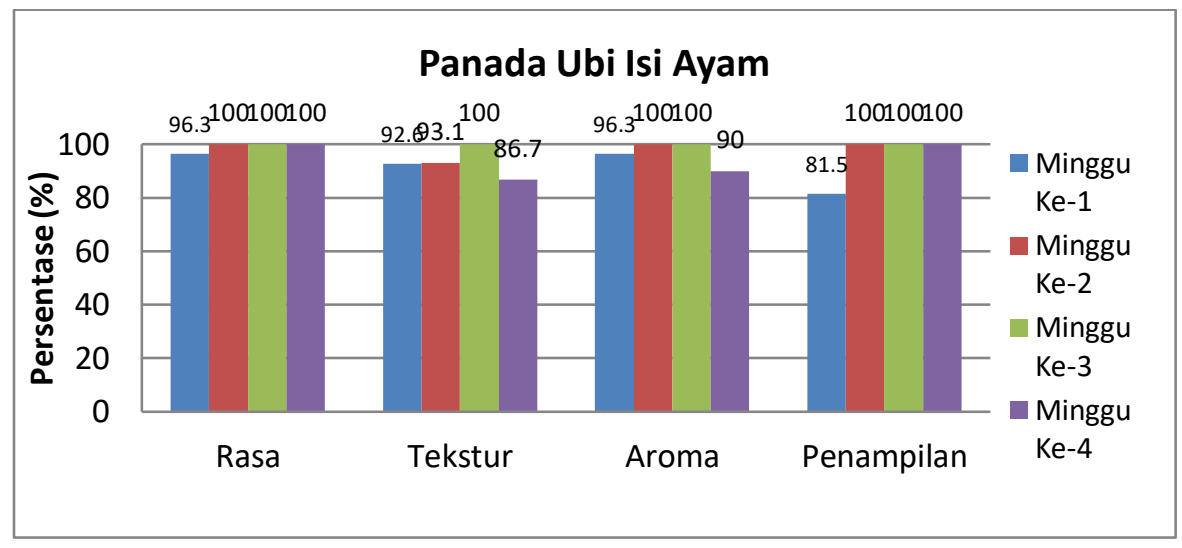

Gambar 2 Diagram daya terima snack panada ubi isi ayam

Hasil uji organoleptik pada snack panada ubi bercita rasa asin, memperlihatkan bahwa dari segi rasa dan penampilan panelis menyukai hidangan tersebut, perubahan yang dilakukan untuk memperbaiki rasa dari panada ubi yaitu dengan menambahkan bumbu yang lebih banyak, sehingga cita rasa dari panada ubi yang memiliki rasa manis untuk dijadikan snack asin menjadi muncul, sehingga perubahan resep yang dilakukan pada minggu kedua dan berikutnya dapat diterima oleh panelis, sedangkan dari penampilan panelispun menyukai dari hidangan panada ubi yang dibuat, adanya pengurangan cairan yang dilakukan sehingga memudahkan untuk membentuk atau memilin panada sehingga penampilan yang dibuat menjadi lebih rapi. Sedangkan untuk tekstur dan aroma perlu dilakukan perbaikan resep kembali, panelis krang menyukai tekstur panada ubi karena jika penggunaan cairan diberikan dalam jumlah banyak akan menyulitkan pada saat membentuk karena ada pengaruh dari penggunaan bahan tambahan ubi yang diberikan, pada ujicoba pertama ubi direbus tetapi hasil yang didapatkan tekstur ubi adonan menjadi lembek, lalu dilakukan perbaikan pengolahan, ubi dikukus untuk mengurangi kandungan air. Sedangkan untuk ujicoba keempat terlalu lama proses fermentasi menyebabkan panada menjadi overmix yang mempengaruhi tekstur dari adonan panada. Sedangkan untuk aroma masih sulit untuk membuat aroma yang disukai oleh panelis, dari uji coba pertama penumisan bumbu kurang matang karena pengaruh juga dari penggunaan bumbu yang terlalu sedikit sehingga mempengaruhi pada saat penumisan dengan menggunakan api yang terlalu besar, sehingga bumbu sudah berwarna coklat tetapi belum matang. Untuk ujicoba berikutnya diperbaiki dari penggunaan api dan tingkat kematangan bumbu sehingga panelis sudah mulai suka, tetapi pada ujicoba keempat karena pengaruh fermentasi yang terlalu lama menyebabkan aroma asam yang tercium sehingga mempengaruhi penilaian panelis terhadap aroma panada ubi. 


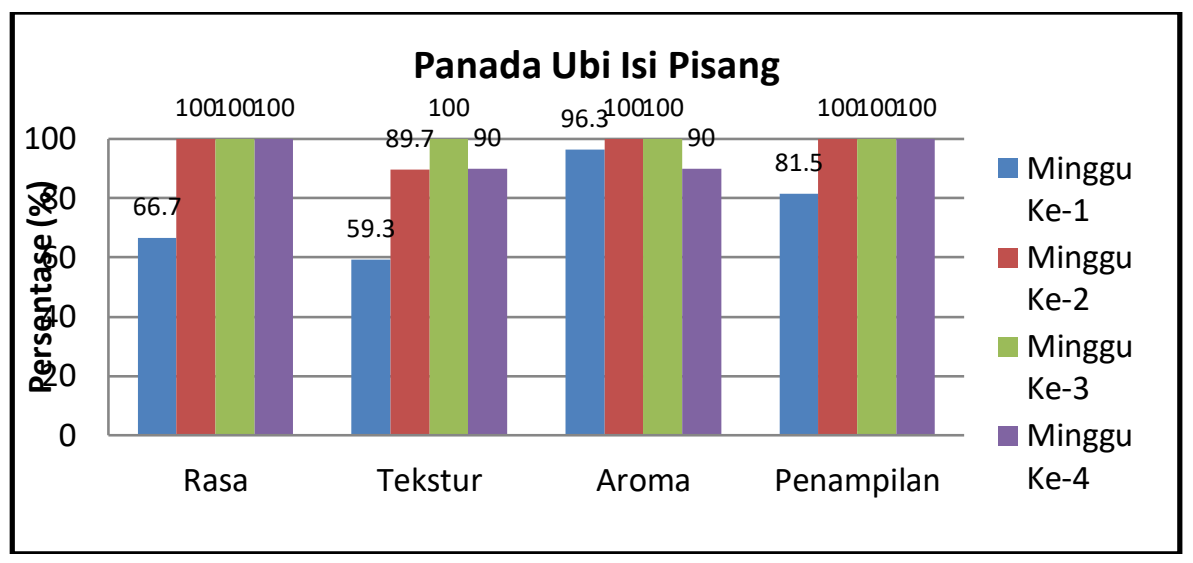

Gambar 3 Diagram daya terima snack panada ubi isi pisang

Kedua produk berupa panada isi pisang, sama seperti pada panada isi ayam, dilihat dari rasa dan penampilan panelis sudah menyukai dari produk yang dikembangkan, untuk aroma panelis juga sudah dikatakan dapat menerima, hy sama hal nya dengan produk panada isi ayam, panelis terganggu dengan aroma asam yang didapat dari proses fermentasi yang terlalu lama. Sedangkan untuk tekstur panelis kurang menyukai disebabkan karena pengunaan pisang, tingkat kematangan pisang sangat berpenaruh pada penilaian panelis erhadap produk yang di buat. Untuk panada isi pisang sangat dipengaruhi oleh tingkat kematangan pisang yang digunakan, peneliti harus trampil dalam memilih pisang yang memiliki tingkat kematangan yang pas sehingga tidak akan mempengaruhi terhadap tekstur dan rasa dari produk yang dihasilkan.

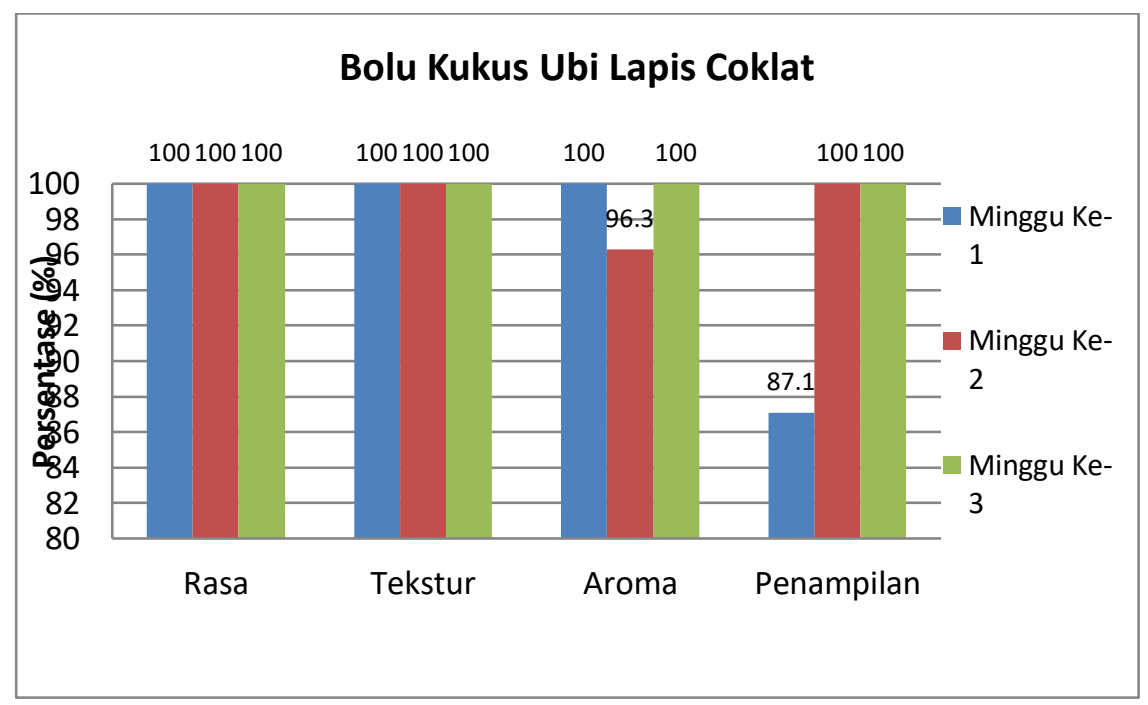

Gambar 4 Diagram daya terima snack bolu kukus ubi lapis coklat

Penilaian uji organoleptik dilakukan dari segi rasa, tekstur, aroma, dan penampilan bolu kukus ubi lapis coklat mempunyai daya terima yang baik dari minggu ke minggu. Namun, pada segi penampilan saat pengolahan minggu pertama kurang baik, dikarenakan lapisan coklat bolu kukus yang menyebar kesamping dan pemotongan bolu yang kurang rapi. Pada minggu kedua, segi aroma mengalami penurunan dikarenakan kurangnya penggunaan vanilli pada bolu kukus lapis coklat. 
Berdasarkan penilaian dari segi rasa, tekstur, aroma, dan penampilan dari bolu kukus ubi lapis tumis ayam sayuran mengalami peningkatan di minggu kedua pengolahan. Namun, dari segi rasa mengalami sedikit penurunan, ini dikarenakan bahan isi tumis ayam sayuran yang sedikit lebih asin daripada biasanya. Pada minggu ketiga pengolahan hasil penilaian stabil tetapi, penampilan mengalami penurun. Hal ini disebabkan lapisan atas pada bolu sedikit kurang rata, sehingga mempengaruhi penampilan.

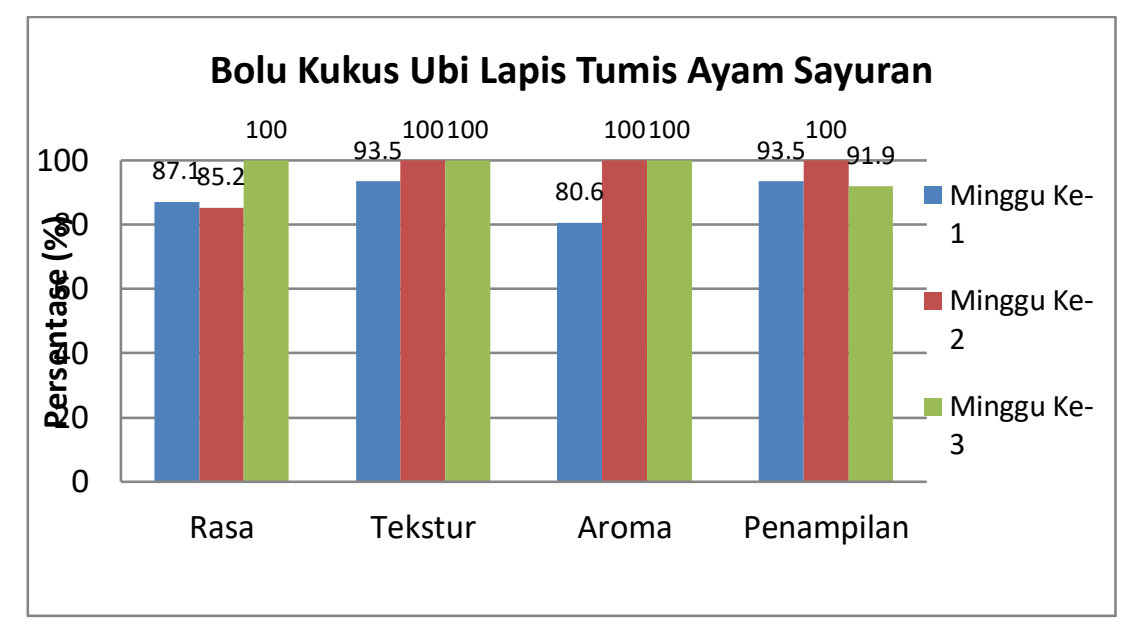

Gambar 5 Diagram daya terima snack bolu kukus ubi lapis tumis bayam sayuran

Melihat perbandingan kedua diagram daya terima snack bolu kukus ubi, dapat disimpulkan bahwa konsumen lebih menyukai bolu kukus ubi lapis coklat. Hal tersebut dikarenakan rasa manis memang sangat cocok untuk hidangan bolu, kombinasi bahan yang digunakan antara ubi jalar merah dan coklat membuat rasa dari bolu kukus ubi menjadi lebih lezat, jika dibandingkan dengan penggunaan bahan isi dengan citarasa gurih atau asin dinilai masih kurang cocok untuk hidangan snack bolu kukus ubi.

Pie ubi coklat mempunyai daya terima yang baik dan stabil dari minggu ke minggu. Namun, dari segi tekstur saat pengolahan minggu pertama kurang baik, dikarenakan kulit pie kurang renyah setelah dipanggang. Selain itu, pada minggu kedua segi aroma mengalami penurunan karena kurangnya penambahan susu bubuk dan vanilli sehingga aroma bahan isi kurang tercium.

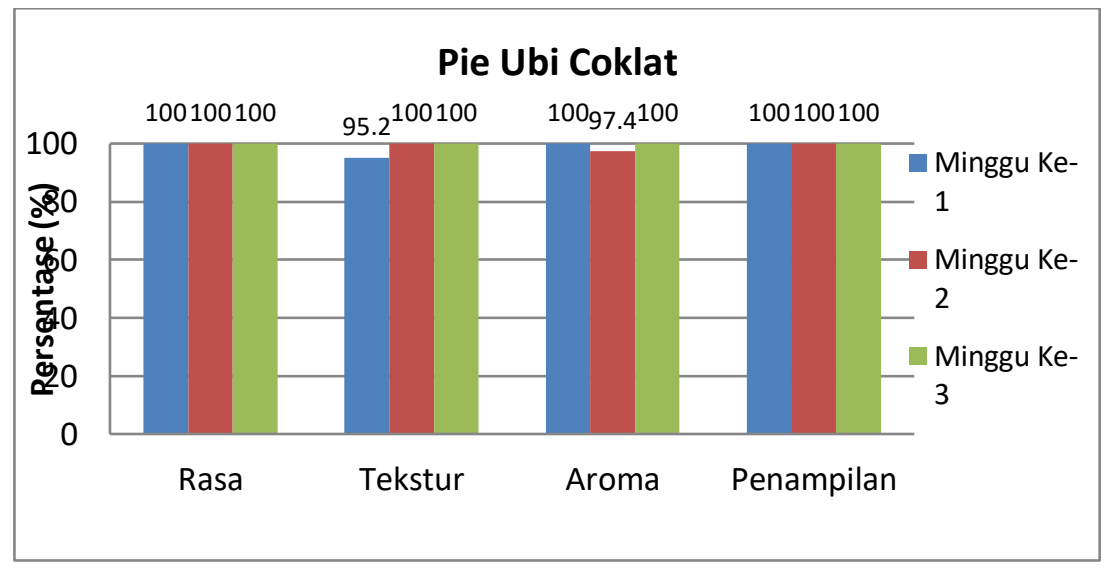

Gambar 6 Diagram daya terima snack pie ubi coklat 
Penilaian uji organoleptik dilakukan dari segi rasa, tekstur, aroma, dan penampilan dari pie ubi isi ragout ayam sayuran mempunyai daya terima yang baik dan stabil dari minggu ke minggu. Namun, dari segi tekstur saat pengolahan minggu pertama kurang baik, dikarenakan kulit pie kurang renyah setelah dipanggang. Selain itu, pada minggu kedua segi rasa mengalami penurunan karena rasa ragout ayam yang lebih asin dari biasanya. Pada minggu ketiga segi rasa sudah sedikit meningkat, tetapi segi tekstur mengalami penurunan. Hal ini disebabkan karena ragout ayam yang terlalu basah sehingga berpengaruh kepada kulit pie saat dipanggang.

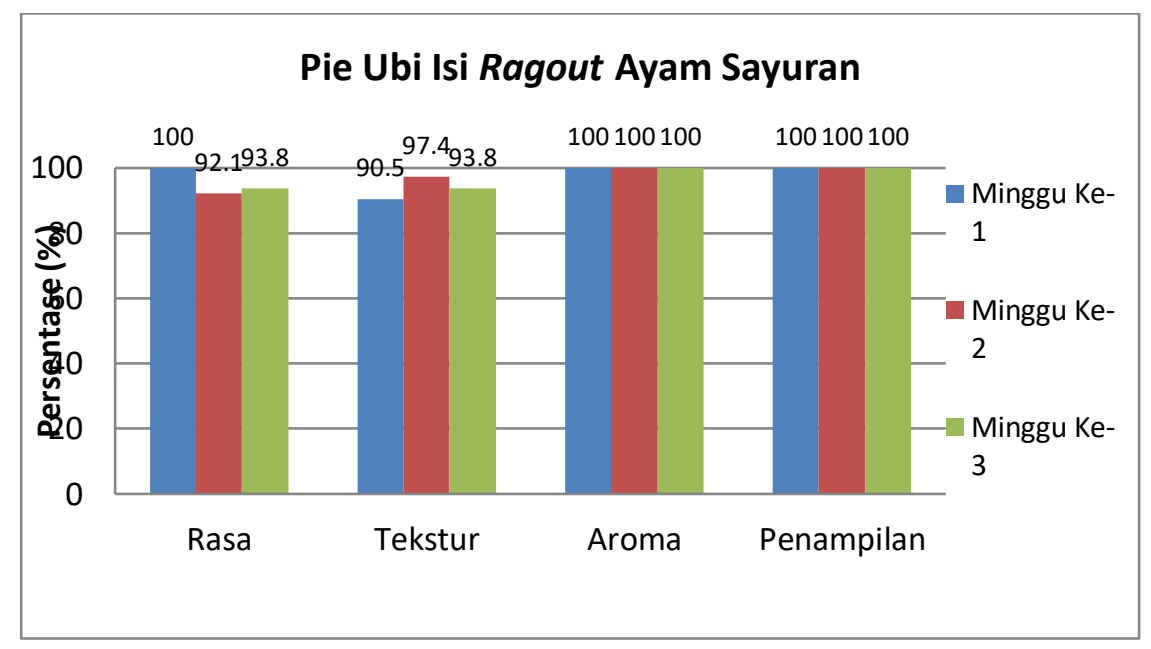

Gambar 7 Diagram daya terima snack pie ubi isi ragout ayam sayuran

Melihat perbandingan kedua diagram daya terima snack pie ubi, dapat disimpulkan bahwa konsumen lebih menyukai pie ubi coklat. Hal tersebut dikarenakan konsumen senang mengkonsumsi vla ubi yang umumnya tidak digunakan pada pie yang dijual dipasaran.

\section{Biaya Bahan dan Harga Jual Snack Ubi Jalar}

Biaya bahan yang diperlukan untuk pengolahan hidangan snack berbahan dasar ubi jalar berupa panada ubi dalam satu kali produksi, dengan total belanja keseluruhannya sebesar Rp. 41.365, sehingga biaya bahan satu kemasannya yaitu Rp. 4.137 untuk panada ubi. Sedangkan hidangan snack bolu kukus ubi dalam satu kali produksi membutuhkan total biaya sebesar Rp. 32.651, dengan biaya bahan satu kemasannya sebesar yaitu Rp. 2.721. Biaya produksi untuk pie ubi membutuhkan total biaya sebesar Rp. 34.030 dengan biaya bahan satu kemasannya yaitu sebesar Rp. 2.618.

Bila dibandingkan antara ketiga hidangan tersebut, biaya bahan yang paling ekonomis dikeluarkan untuk memproduksi hidangan snack bolu kukus ubi, hal ini disebabkan karena harga bahan yang digunakan tidak terlalu mahal dan jenis bahan yang dibeli tidak terlalu banyak. Persentase biaya bahan per harga jual untuk panada ubi $82,7 \%$, bolu kukus $68 \%$, dan pie ubi $65,4 \%$.

\section{SIMPULAN}

Berdasarkan hasil kajian pengembangan produk snack berbahan dasar ubi jalar dapat disimpulkan beberapa hal :

- Produk snack berbahan dasar ubi jalar merupakan salah satu produk modifikasi dari beberapa snack pada umumnya. Beberapa produk yang diolah yaitu panada ubi jalar, bolu kukus ubi, dan pie ubi. Ubi jalar dijadikan 
sebagai bahan dasar olahan karena bahan dasar ini mudah dalam pengolahannya, mudah didapat, harga yang terjangkau, memiliki nutrisi yang baik bagi tubuh, dan mempunyai daya simpan yang lama.

- Pengadaan bahan makanan snack ubi jalar dilakukan satu hari sebelum proses produksi. Pembelian bahan dilakukan pada pukul 15.00-16.00 WIB. Pengadaan dan pembelian bahan makanan dilakukan setelah adanya perencanaan. Setelah itu dilakukan penyimpanan berdasarkan bahan kering dan bahan basah. Proses selanjutnya yaitu dilakukan persiapan untuk kemudian diolah.

- Produksi snack ubi jalar yang paling sulit adalah produksi snack panada ubi. Hal ini dikarenakan langkah kerja untuk membuat panada ubi lebih banyak dibandingkan dengan langkah kerja pembuatan snack lainnya, seperti pengulenan adonan, fermentasi, penggilingan adonan, pengisian bahan isi dan menggoreng panada. Selain itu, waktu yang dibutuhkan untuk pembuatan snack ini juga lebih lama dibandingkan dengan snack lainnya.

- Kandungan energi dan zat gizi yang paling tinggi diantara ketiga hidangan snack ubi jalar adalah pie ubi dengan kandungan Energi sebesar $301 \mathrm{Kal}$, Protein $6.3 \mathrm{~g}$, Lemak $17.7 \mathrm{~g}$, dan Karbohidrat sebesar $27.2 \mathrm{~g}$. Kandungan energi dan zat gizi pada pie ubi tinggi karena banyak menggunakan margarin dalam pengolahannya. Namun, walaupun memiliki kandungan energi dan zat gizi yang lebih tinggi dibandingkan dengan hidangan lainnya, pie ubi masih memenuhi standar maksimal kandungan gizi.

- Dari ketiga hidangan snack ubi jalar yang paling diterima dan digemari konsumen adalah panada ubi isi ayam. Hidangan ini paling digemari karena panada merupakan hidangan yang identik dengan rasa gurih dan dengan olahan isi berupa ayam yang lebih digemari dibandingkan ikan cakalang. 


\section{DAFTAR PUSTAKA}

Alma B. 2011. Manajemen Pemasaran dan Pemasaran Jasa. Bandung (ID): CV Alfabeta.

[BPPP] Badan Penelitian dan Pengembangan Pertanian. 2012. Aneka Olahan Umbi. Jakarta (ID): Kementrian Pertanian.

Ismayani Y. 2009. 100+ Tip Antigagal Bikin Kue. Jakarta (ID): PT Kawan Pustaka.

[KEMENKES RI] Kementrian Kesehatan Republik Indonesia. 2013. Pedoman Pelayanan Gizi Rumah Sakit. Jakarta (ID). Kementrian Kesehatan.

Muhardi. 2007. Strategi Operasi untuk Keunggulan Bersaing. Yogyakarta (ID): Graha IImu.

Richana N. 2012. Ubi Jalar dan Ubi Kayu: Botani, Budidaya, Teknologi Proses, Teknologi Pasca Panen. Bandung (ID) : Nuansa.

Winarti S. 2010. Makanan Fungsional. Yogyakarta (ID): Graha Ilmu.

Yuyun A, Gunarsa D. 2011. Cerdas Produk Makanan \& Minuman. Jakarta (ID): PT Agromedia Pustaka. 